\title{
Leaf Protein Abundance Associated with Improved Drought Tolerance by Elevated Carbon Dioxide in Creeping Bentgrass
}

\author{
Patrick Burgess and Bingru Huang ${ }^{1}$ \\ Department of Plant Biology and Pathology, Rutgers University, New Brunswick, NJ 08901
}

\begin{abstract}
AdDitional INDEX wORDs. photosynthesis, proteomics, respiration, turfgrass
Abstract. Elevated $\mathrm{CO}_{2}$ may contribute toward plant tolerance to prolonged drought stress. The objective of this study was to investigate changes in protein abundance associated with mitigation of drought stress by elevated $\mathrm{CO}_{2}$ in leaves of a cool-season grass species used as fine turfgrass. Plants of creeping bentgrass (Agrostis stolonifera cv. Penncross) were grown at either ambient $\mathrm{CO}_{2}$ concentration $\left(400 \mu \mathrm{L} \cdot \mathrm{L}^{-1}\right)$ or elevated $\mathrm{CO}_{2}$ concentration $\left(800 \mu \mathrm{L} \cdot \mathrm{L}^{-1}\right)$ for 35 days under well-irrigated and fertilized conditions and then subjected to drought stress for 21 days by withholding irrigation. Plants exposed to elevated $\mathrm{CO}_{2}$ concentration maintained higher leaf water content, membrane stability, and visual turf quality (TQ) under drought stress compared with plants grown under ambient $\mathrm{CO}_{2}$ conditions. The abundance of proteins involved in photosynthetic carbon fixation and assimilation, including chloroplastic glyceraldehyde phosphate dehydrogenase A (GAPDH-A) and ribulose 1,5-bisphosphate carboxylase (RuBisCO) decreased less and the abundance of proteins involved in respiratory metabolism (i.e., cytosolic GAPDH) increased less during drought due to elevated $\mathrm{CO}_{2}$. The results suggest that elevated $\mathrm{CO}_{2}$ lessened growth and physiological damages during drought by facilitating ribulose 1,5-bisphosphate regeneration and adenosine triphosphate (ATP) production in photosynthesis and downregulating factors contributing to respiratory metabolism.
\end{abstract}

Drought stress due to the lack of rainfall and declining availability of fresh water for irrigation is a primary factor limiting growth and productivity of many plant species. Within the context of global climate change, precipitation amounts and frequencies have changed drastically over the past century and many regions are now experiencing drought episodes more frequently (Solomon et al., 2007). Drought stress imposes many physiological limitations throughout the plant system encompassing damages at the biochemical, metabolic, and cellular levels (Aroca, 2012). Along with an increasing frequency of drought events, anthropogenic $\mathrm{CO}_{2}$ emissions are driving a steady increase in atmospheric $\mathrm{CO}_{2}$ concentrations of $\approx 2-3$ $\mu \mathrm{L} \cdot \mathrm{L}^{-1}$ per year and plants may therefore be exposed to prolonged drought stress under elevated $\mathrm{CO}_{2}$ concentrations in the near future (Solomon et al., 2007). The effects of elevated $\mathrm{CO}_{2}$ concentration on many aspects of plant development and function under nonstress conditions have been well-documented and generally positive effects of elevated $\mathrm{CO}_{2}$ concentration on plant growth are reported in various plant species (Ainsworth et al., 2002; Ceulemans and Mousseau, 1994; Huang and Xu, 2015; Kirkham, 2011; Leakey et al., 2009; Peterson et al., 1999). Recent research has also demonstrated that elevated $\mathrm{CO}_{2}$ may mitigate physiological damages due to abiotic stress, such as drought and heat, in various plant species including perennial grasses such as kentucky bluegrass (Poa pratensis) and tall fescue (Festuca arundinacea) (Lin and Wang, 2002; Qaderi et al., 2006; Wall et al., 2001; Yu et al., 2012). Despite the abundant knowledge regarding the positive

Received for publication 15 Oct. 2015. Accepted for publication 26 Nov. 2015. The mass spectrometry data were obtained from an Orbitrap instrument funded in part by an NIH grant NS046593 for the support of the Rutgers Neuroproteomics Core Facility.

${ }^{1}$ Corresponding author. E-mail: huang@aesop.rutgers.edu. effects of elevated $\mathrm{CO}_{2}$ on plant growth under nonstress or stress conditions, the underlying mechanisms by which elevated $\mathrm{CO}_{2}$ attenuates the damaging effects of prolonged drought stress remain unclear and require further investigation.

Proteomic profiling of stress-responsive proteins by means of two-dimensional polyacrylamide gel electrophoresis separation and mass spectrometry (MS) identification has effectively described changes in proteomic abundance within various tissues of different plant species responding to abiotic stresses (Burgess and Huang, 2014; Ferreira et al., 2006; Huang et al., 2014; Jespersen et al., 2015; Kosová et al., 2011; Merewitz et al., 2011). In response to drought stress alone, the abundance of proteins involved in photosynthesis, membrane synthesis, cell wall loosening, cell turgor maintenance, and antioxidant defense decrease in drought-susceptible grasses and the decrease is less severe in drought-tolerant species or cultivars (Xu and Huang, 2010a, 2012a). Under elevated $\mathrm{CO}_{2}$ alone, many of the proteins serving integral photosynthetic functions in the light reactions and light-independent reactions have decreased abundance but compensate with significantly higher enzyme activity or activation state (Yu et al., 2014). The majority of proteomic research related to drought stress has identified drought-responsive changes in protein abundance under ambient $\mathrm{CO}_{2}$ concentration only while changes in protein abundance responding to the combined drought stress and elevated $\mathrm{CO}_{2}$ are not well documented, although differential abundance of proteins affected by elevated $\mathrm{CO}_{2}$ under drought stress from those under well-irrigated conditions could serve critical roles for $\mathrm{CO}_{2}$ mitigation of drought damages. The main focus of the current study was on the analysis of $\mathrm{CO}_{2}$-responsive proteins under well-irrigated or drought conditions or protein abundance altered by the combined $\mathrm{CO}_{2}$ and drought stress.

Therefore, the objective of this study was to investigate changes in protein abundance responding to interactive effects 
of drought and $\mathrm{CO}_{2}$ in leaves of creeping bentgrass, widely used as fine turfgrass, with a goal to suggest potential metabolic factors regulated by elevated $\mathrm{CO}_{2}$ contributing to improved drought tolerance.

\section{Materials and Methods}

Plant material and growth conditions. Thirty uniformsize tillers from creeping bentgrass (cv. Penncross) plants were transplanted from the Rutgers University turfgrass research farm (New Brunswick, NJ) into each pot $(10 \mathrm{~cm}$ diameter and $40 \mathrm{~cm}$ depth) filled with fritted clay medium (Profile Products, Deerfield, IL) on 10 May 2014 and plants were maintained in controlled-environment growth chambers (Environmental Growth Chambers, Chagrin Falls, $\mathrm{OH}$ ) set to $21 / 18{ }^{\circ} \mathrm{C}$ (day/night), $650 \mu \mathrm{mol} \cdot \mathrm{m}^{-2} \cdot \mathrm{s}^{-1}$ photosynthetically active radiation, $60 \%$ relative humidity, and $14-\mathrm{h}$ photoperiod for $7 \mathrm{~d}$ to allow plant acclimation to growth chamber conditions before exposing plants to $\mathrm{CO}_{2}$ treatments on 18 May 2014.

Treatments AND EXPERIMENTAL Design. Twenty pots ( 4 treatments $\times 5$ replicates) of plants were established for $35 \mathrm{~d}$ (18 May to 21 June 2014 ) at ambient $\left(400 \mu \mathrm{L} \cdot \mathrm{L}^{-1}\right)$ or elevated $\left(800 \mu \mathrm{L} \cdot \mathrm{L}^{-1}\right) \mathrm{CO}_{2}$ concentration under well-irrigated conditions with excess water draining from pot bases and fertilized twice per week with half-strength Hoagland's nutrient solution (Hoagland and Arnon, 1950). Following establishment under either $\mathrm{CO}_{2}$ concentration, all plants were irrigated to pot capacity on 22 June 2014 (0-d drought stress) and subjected to drought stress for $21 \mathrm{~d}$ (23 June to 13 July 2014) by withholding irrigation until volumetric soil water content (SWC) decreased to $7.0 \%$ or irrigated to maintain SWC at the pot capacity $(\approx 29 \%$ ) as the nonstress control. During 21-d drought stress, plants were continually exposed to either ambient or elevated $\mathrm{CO}_{2}$ concentration.

The ambient and elevated $\mathrm{CO}_{2}$ concentrations within growth chambers were maintained through an automatic $\mathrm{CO}_{2}$ controlling system connected to a source tank containing $100 \%$ research-grade $\mathrm{CO}_{2}$ following the method described in $\mathrm{Yu}$ et al. (2012). $\mathrm{CO}_{2}$ concentrations inside the chambers were continuously monitored and recorded using an infrared gas analyzer (LI-820; LI-COR, Lincoln, NE) connected to a computer data logger. The $\mathrm{CO}_{2}$ concentration was maintained using an automatic controlling system consisting of a programmable logic controller unit, solenoid valves, and a laptop computer with software capable of monitoring and maintaining $\mathrm{CO}_{2}$ concentration within $10 \mu \mathrm{L} \cdot \mathrm{L}^{-1}$ of the ambient or elevated target levels.

The experiment was arranged in a split-plot design with $\mathrm{CO}_{2}$ treatment (ambient or elevated) as the main plot and irrigation treatment (well irrigated or drought stress) as the sub-plot. Each $\mathrm{CO}_{2}$ treatment was performed in four different growth chambers and five replicate pots of well-irrigated or drought treatments were randomly placed inside each growth chamber. All plants were relocated between the four growth chambers every $3 \mathrm{~d}$ to avoid possible confounding effects of unique growth chamber environmental variations from occurring.

SoIL WATER STATUS AND PHYSIOLOGICAL ANALYSIS. The SWC was monitored daily using a time reflectometer (Trase System 1; Soilmoisture Equipment Corp., Santa Barbara, CA). Three buriable waveguide probes, each measuring $30 \mathrm{~cm}$ in length, were inserted into the root zone and SWC was measured in drought-stressed and well-irrigated treatments (Topp et al., 1980).

Leaf relative water content (RWC) was measured to indicate leaf hydration status following $21 \mathrm{~d}$ of drought treatment. About $0.2 \mathrm{~g}$ leaf tissue of second and third fully expanded leaves was collected and fresh weight (FW) measured using a mass balance immediately after harvesting. Leaves were then wrapped in tissue paper, submerged in deionized water for $12 \mathrm{~h}$ at $4{ }^{\circ} \mathrm{C}$, removed from water, blotted dry, and again weighed to measure turgid weight (TW). Leaves were then dried in an oven at $80^{\circ} \mathrm{C}$ for $3 \mathrm{~d}$, weighed to determine dry weight (DW) and RWC (percent) calculated using the formula $[(\mathrm{FW}-\mathrm{DW}) /(\mathrm{TW}-$ DW) $] \times 100$ (Barrs and Weatherley, 1962).

Leaf membrane stability was estimated by measuring cellular electrolyte leakage (EL) following $21 \mathrm{~d}$ of drought treatment. About $0.2 \mathrm{~g}$ leaf tissue of second and third fully expanded leaves was collected, rinsed with deionized water to remove external solutes, and placed in a test tube containing $30 \mathrm{~mL}$ deionized water. Tubes were agitated on a conical flask shaker for $12 \mathrm{~h}$ and the initial conductance $\left(C_{\mathrm{i}}\right)$ of incubation solution measured using a conductivity meter (YSI, Yellow Springs, OH). Leaf tissue was then killed by autoclaving at $121{ }^{\circ} \mathrm{C}$ for $20 \mathrm{~min}$, cooled to room temperature, agitated for $12 \mathrm{~h}$, and the maximal conductance $\left(C_{\max }\right)$ of incubation solution was measured. Leaf EL (percent) was calculated using the formula $\left(C_{\mathrm{i}} / C_{\max }\right) \times 100$ (Blum and Ebercon, 1981).

Visual evaluation of TQ was performed to indicate overall turfgrass performance on a scale of 1 to 9 with 1 being brown and dead turf, 6 being the minimum acceptable quality level, and 9 being green and healthy turf. TQ ratings were based on parameters such as canopy uniformity, density, and color (Beard, 1973).

Protein extraction, SeParation, Quantification, AND IDENTIFICATION. Protein extraction and separation were performed using the acetone/trichloroacetic acid extraction and two-dimensional gel electrophoresis method of $\mathrm{Xu}$ et al. (2008). Following $21 \mathrm{~d}$ of drought stress, second and third fully expanded leaves were collected, immediately frozen in liquid nitrogen, and stored at $-80{ }^{\circ} \mathrm{C}$ for protein analysis. About $0.4 \mathrm{~g}$ leaf tissue was ground to powder in liquid nitrogen and further homogenized in $4 \mathrm{~mL}$ ice-cold precipitation solution (10\% trichloroacetic acid, $0.07 \%$ 2-mercaptoethanol in acetone) for $12 \mathrm{~h}$ at $-20^{\circ} \mathrm{C}$. Precipitated leaf tissue was centrifuged at $11,600 \mathrm{~g}$ for $15 \mathrm{~min}$ at $4{ }^{\circ} \mathrm{C}$, the supernatant was removed and the remaining pellet was washed three times with rinse solution $(0.07 \%$ 2-mercaptoethanol in acetone). The remaining pellet was vacuum dried at room temperature and resuspended in $2 \mathrm{~mL}$ resolubilization solution $\{8 \mathrm{M}$ urea, $2 \mathrm{M}$ thiourea, $1 \% 3$ [(3-cholamidopropyl) dimethylammonio]-1-propanesulfonate, $1 \%$ dithiothreitol, 1\% 3/10 biolytes $\}$. Aliquots of the resulting protein solution were then used to determine protein concentration according to Bradford (1976) using a commercial dye reagent (Bio-Rad Laboratories, Hercules, CA) and bovine serum albumin as the standard. Immobiline DryStrips $(\mathrm{pH}$ 3-10, linear gradient, $13 \mathrm{~cm}$; GE Healthcare, Piscataway, NJ) were rehydrated with $250 \mu \mathrm{g}$ resolubilized protein and loaded onto an IPGphor apparatus (GE Healthcare) for first dimension separation. The voltage settings for first dimension isoelectric focusing were $50 \mathrm{~V}$ for $14 \mathrm{~h}, 500 \mathrm{~V}$ for $1 \mathrm{~h}, 1000 \mathrm{~V}$ for $1 \mathrm{~h}$, $5000 \mathrm{~V}$ for $1 \mathrm{~h}$, and $8000 \mathrm{~V}$ to a total of $80 \mathrm{kVh}$. Following first dimension focusing, strips were denatured in $10 \mathrm{~mL}$ equilibration buffer [50 mM Tris-Base ( $\mathrm{pH} 8.7$ ), $6 \mathrm{~m}$ urea, 30\% glycerol, 
$2 \%$ sodium dodecyl sulfate, $0.002 \%$ bromophenol blue, and $1 \%$ dithiothreitol] for $20 \mathrm{~min}$ and incubated again in the same buffer with dithiothreitol replaced with $2.5 \%$ iodoacetamide. An electrophoresis unit (Hoefer SE 600 Ruby; GE Healthcare) was used to perform second dimension electrophoresis on a $12.5 \%$ sodium dodecyl sulfate-polyacrylamide gel $\{42 \%$ monomer solution (30\% acrylamide and $0.8 \%$ N,N'-Methylenebiscarylamide), $25 \%$ resolving gel buffer $[1.5 \mathrm{~m}$ Tris-Base and $6 \mathrm{~N}$ hydrochloric acid $(\mathrm{pH} 8.8)], 0.01 \%$ sodium dodecyl sulfate, $3.4 \mathrm{ppm}$ tetramethylethylenediamine, and $50 \mathrm{ppm}$ ammonium persulfate $\}$. Voltage settings for second dimension electrophoresis were $5 \mathrm{~mA}$ per gel for $30 \mathrm{~min}$ followed by $20 \mathrm{~mA}$ per gel for $6.5 \mathrm{~h}$. Gels were stained with colloidal Coomassie Brilliant Blue G-250 stain (Neuhoff et al., 1988) and scanned on a Typhoon FLA 9500 (GE Healthcare) to generate digital gel images. Gel images were analyzed using SameSpots software (version 4.5; Nonlinear USA, Durham, NC) and protein volumes were normalized as a percentage of total protein volume to correct for variability during staining. Proteins with probability values less than or equal to 0.05 were chosen for further identification by reversed-phase liquid chromatography (RPLC).

Proteins chosen for identification were manually excised from gels and washed with $30 \%$ acetonitrile in $50 \mathrm{~mm}$ ammonium bicarbonate solution before dithiothreitol reduction and iodoacetamide alkylation. Trypsin was used for digestion at $37{ }^{\circ} \mathrm{C}$ overnight. The resulting peptides were extracted with $30 \mu \mathrm{L} 1 \%$ trifluoroacetic acid followed by $\mathrm{C}_{18}$ ziptip desalting to simultaneously remove salts and concentrate the peptides. Peptides were further fractionated by RPLC on a LC system (Ultimate 3000; Dionex, Sunnyvale, CA) coupled to a mass spectrometer (Q-Exactive; Thermo Fisher Scientific, Waltham, MA) with a nano-electrospray ionization source (Thermo Fisher Scientific). Source ionization parameters included a $2.2-\mathrm{kV}$ spray voltage, $275{ }^{\circ} \mathrm{C}$ capillary temperature, and 50.0 s-lens. Full-scan MS mode [300-1650 m/z (mass-tocharge ratio)] was operated at a resolution of 70,000, automatic gain control (AGC) target was $1 \times 106$, and maximum ion transfer time (IT) was $500 \mathrm{~ms}$. MS/MS parameters for selected ions included 17,500 resolution, $5 \times 104 \mathrm{AGC}, 250 \mathrm{~ms}$ IT, $4.0 \mathrm{~m} / \mathrm{z}$ isolation window, 25.0 normalized collision energy, $5.0 \%$ underfill ratio, and a $30 \mathrm{~s}$ dynamic exclusion.

Raw files were analyzed using the Proteome Discoverer software platform (version 1.3, Thermo Fisher Scientific) with Mascot (2.4.1) search engine against the Green plant protein sequences $(1,474,035$ entries) of nonredundant National Center for Biotechnology Information protein database. Mascot parameters included trypsin, two missed cleavages, $10 \mathrm{ppm}$ precursor mass tolerance, $0.1 \mathrm{Da}$ fragment mass tolerance, as well as methionine oxidation and cysteine carbamidomethylation dynamic modifications with decoy search option for Mascot engaged. Proteins with 100\% peptide spectral match were considered to be present throughout the majority of analyzed proteins.

Statistical analysis. The effects of $\mathrm{CO}_{2}$ level, irrigation regimen, and their interactions on physiological parameters, protein abundance, and relative protein accumulation were determined by analysis of variance according to the general linear model procedure of SAS (version 9.2; SAS Institute, Cary, NC). Differences between treatment means were separated by Fisher's protected least significance difference test $(\alpha=0.05)$.

\section{Results and Discussion}

A characteristic response of drought-susceptible plants is a steady decline in cellular water content concurrent with dysfunction and eventual failure of cellular membranes, along with numerous other metabolic and biochemical changes (Kopp and Jiang, 2013). Drought stress caused significant reduction in $\mathrm{RWC}$ under both ambient and elevated $\mathrm{CO}_{2}$ concentrations (Fig. 1A) when SWC decreased to $\approx 7.0 \%$ following $21 \mathrm{~d}$ of drought stress (Fig. 2). Drought-induced reduction in RWC was more pronounced (by 42\%) under ambient $\mathrm{CO}_{2}$ concentration than that under elevated $\mathrm{CO}_{2}$ concentration (by 28\%) following $21 \mathrm{~d}$ of drought stress. Elevated $\mathrm{CO}_{2}$ treatment led to significantly higher (by 19\%) RWC compared with the ambient $\mathrm{CO}_{2}$ treatment following drought stress whereas no significant changes in RWC were observed with elevated $\mathrm{CO}_{2}$ under well-irrigated conditions (Fig. 1A). Maintaining adequate water content within cells or delaying cellular dehydration during stress periods in $\mathrm{CO}_{2}$ enriched plants may be due to the effects of elevated $\mathrm{CO}_{2}$ on the induction of stomatal closure restricting transpirational water loss and enhanced osmotic adjustment due to the accumulation of solutes, such as soluble sugars, as well as enhanced root growth for water uptake (Leakey et al., 2009; Yu et al., 2015). Maintenance of photosynthetic processes has also been associated with improved RWC during drought stress in other cool-season turfgrass species, such as tall fescue (Yu et al., 2012). Moreover, elevated $\mathrm{CO}_{2}$ has been shown to enhance root growth in creeping bentgrass (Burgess and Huang, 2014), which could access more water from soil and contribute to the improvement of leaf water status under drought stress.

Cellular membrane stability evaluated by quantifying ion leakage is a commonly used indicator for cell integrity and viability in various plant tissues (Jambunathan, 2010). Leaf EL significantly increased with drought stress under either ambient or elevated $\mathrm{CO}_{2}$ concentration following 21-d drought treatment (Fig. 1B). Drought-induced increase in EL was greater (by $51 \%$ ) under ambient $\mathrm{CO}_{2}$ concentration that under elevated $\mathrm{CO}_{2}$ concentration (by $43 \%$ ) following drought stress. Elevated $\mathrm{CO}_{2}$ treatment led to significantly lower (by 18\%) EL compared with the ambient $\mathrm{CO}_{2}$ treatment following drought stress whereas no significant changes in EL were observed with elevated $\mathrm{CO}_{2}$ under well-irrigated conditions (Fig. 1B). The results demonstrate that elevated $\mathrm{CO}_{2}$ treatment effectively mitigated drought-induced cellular membrane deterioration or facilitated maintenance of membrane integrity. Similar results of elevated $\mathrm{CO}_{2}$ effects on membrane stability of droughtstressed plants have been reported in tall fescue ( $\mathrm{Yu}$ et al., 2012). Despite elevated $\mathrm{CO}_{2}$ promoting osmotic adjustment and stomatal constriction with secondary effects on membrane status, the mechanisms by which elevated $\mathrm{CO}_{2}$ contributes directly to cellular membrane stability remain largely unknown, though it was suggested that elevated $\mathrm{CO}_{2}$ treatment increases leaf antioxidant content to reduce reactive oxygen species (ROS) content in spring wheat (Triticum aestivum) and barley (Hordeum vulgare) cultivars (Lin and Wang, 2002; Pérez-López et al., 2009). Whether elevated $\mathrm{CO}_{2}$ conditions stimulate cool-season turfgrass species to use similar antioxidant mechanisms mitigating ROS accumulation thereby delaying significant membrane damages during stress periods is not yet known and deserves further investigation. 

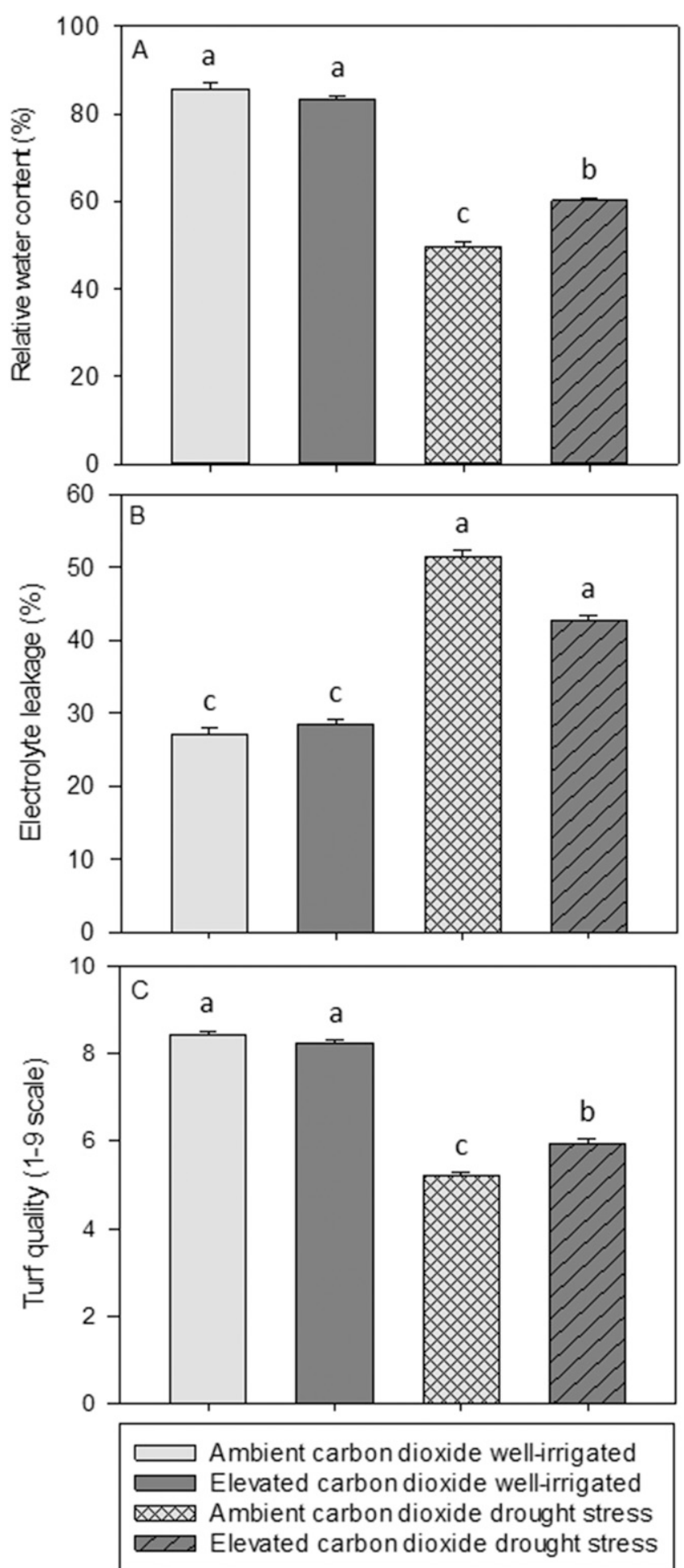

Fig. 1. Changes in (A) leaf relative water content, (B) leaf electrolyte leakage, and $(\mathbf{C})$ turf quality of creeping bentgrass plants exposed to ambient $\left(400 \mu \mathrm{L} \cdot \mathrm{L}^{-1}\right)$ or elevated $\left(800 \mu \mathrm{L} \cdot \mathrm{L}^{-1}\right) \mathrm{CO}_{2}$ concentration for $35 \mathrm{~d}$ followed by well-irrigated or drought-stress conditions for $21 \mathrm{~d}$. Turf quality is rated on a scale of $1-9(1=$ brown and dead turf, $6=$ minimum acceptable quality level, and $9=$ green and healthy turf). Vertical lines atop bars represent SE of five replicates for each treatment and different letters atop bars indicate significant differences between treatments exist according to Fisher's least significant difference test $(\alpha=0.05)$

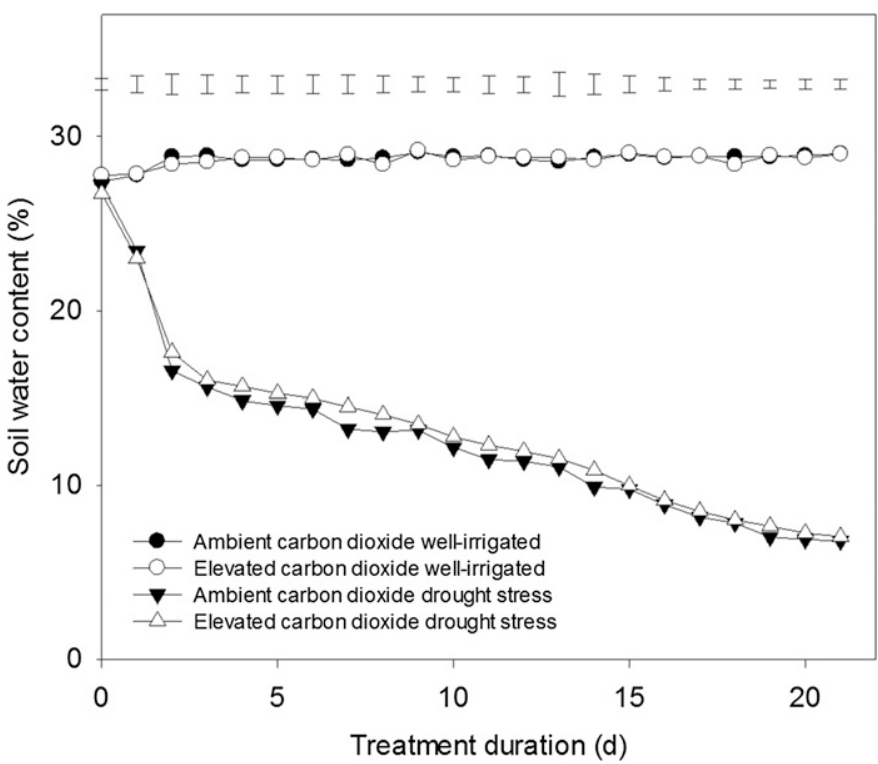

Fig. 2. Soil volumetric water content of creeping bentgrass exposed to ambient $\left(400 \mu \mathrm{L} \cdot \mathrm{L}^{-1}\right)$ or elevated $\left(800 \mu \mathrm{L} \cdot \mathrm{L}^{-1}\right) \mathrm{CO}_{2}$ concentration for $35 \mathrm{~d}$ followed by well-irrigated or drought-stress conditions for $21 \mathrm{~d}$. Vertical lines atop bars represent least significant difference values where significant differences between treatments exist according to Fisher's least significant difference test $(\alpha=0.05)$.

Visual evaluation of turfgrass quality is a subjective criteria commonly used to evaluate overall turfgrass performance based on visual characteristics including canopy density, leaf color, and uniformity (Beard, 1973). Visual TQ displayed significant decrease with drought stress under either ambient or elevated $\mathrm{CO}_{2}$ concentration following 21-d drought treatment (Fig. 1C). Drought-induced reduction in TQ was more pronounced (by $38 \%$ ) under ambient $\mathrm{CO}_{2}$ concentration than that under elevated $\mathrm{CO}_{2}$ concentration (by $28 \%$ ) following $21 \mathrm{~d}$ of drought stress. Elevated $\mathrm{CO}_{2}$ treatment led to significantly higher (by $13 \%$ ) TQ compared with the ambient $\mathrm{CO}_{2}$ treatment following drought stress whereas no significant changes in $\mathrm{TQ}$ were observed with elevated $\mathrm{CO}_{2}$ under well-irrigated conditions (Fig. 1C). The promotive effects of elevated $\mathrm{CO}_{2}$ on TQ corresponded to enhanced RWC and decreased EL during drought stress, both of which are strongly correlated to TQ for creeping bentgrass during drought stress in turfgrasses (Jespersen et al., 2013; Sun et al., 2013). The improved growth and physiological characteristics favoring plant tolerance to drought stress as affected by elevated $\mathrm{CO}_{2}$ concentration could be associated with changes in abundance for specific proteins involved in several major metabolic processes, as discussed below.

As discussed in the introduction, most proteomic research related to drought stress has identified drought-responsive changes in protein abundance under ambient $\mathrm{CO}_{2}$ concentration only. Our study focused on the analysis of $\mathrm{CO}_{2}$-responsive changes in protein abundance under well-irrigated or drought conditions or protein abundance altered by the combined $\mathrm{CO}_{2}$ and drought stress. Over 300 proteins were detected on each two-dimensional gel in leaves of creeping bentgrass (Fig. 3) and 37 proteins successfully identified by RPLC-MS exhibited differential abundance (upregulated or downregulated) in response to elevated $\mathrm{CO}_{2}$ concentration under well-irrigated or drought-stress conditions. Those proteins were categorized into 


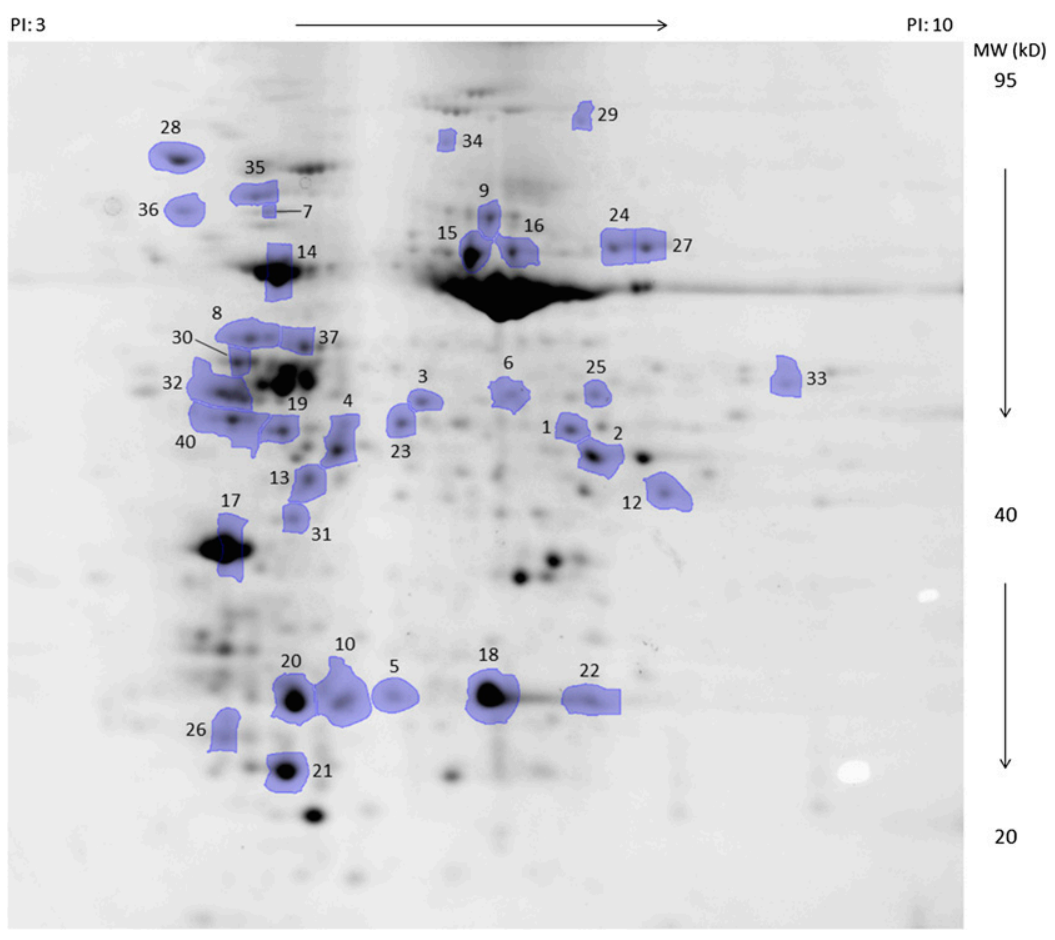

Fig. 3. An example represents two-dimensional electrophoresis gel of creeping bentgrass leaf soluble proteins stained with Coomassie Brilliant Blue. Numbers of highlighted proteins correspond with proteins numbers in Table 1 for proteins exhibiting significant changes in abundance following exposure to ambient $\left(400 \mu \mathrm{L} \cdot \mathrm{L}^{-1}\right)$ or elevated $\left(800 \mu \mathrm{L} \cdot \mathrm{L}^{-1}\right) \mathrm{CO}_{2}$ concentration for $35 \mathrm{~d}$ followed by well-irrigated or drought-stress conditions for $21 \mathrm{~d}$.

five functional categories according to the criteria set forth by Bevan et al. (1998): energy production, stress defense, metabolism, protein destination and storage, and protein synthesis (Table 1). Among the 37 identified proteins, $67.6 \%, 8.1 \%$, $16.2 \%, 5.4 \%$, and $2.7 \%$ served functions in energy production, stress defense, metabolism, protein destination and storage, and protein synthesis functions, respectively (Fig. 4). A total of 18 proteins $(1-6,11,17,18,23,24,26,30-33,36$, and 37) were upregulated and 19 proteins $(7-10,12-16,19-22,25,27-29$, 34 , and 35) were downregulated by elevated $\mathrm{CO}_{2}$ under wellirrigated conditions (Figs. 5, 6A and B).

Elevated $\mathrm{CO}_{2}$ upregulated 20 proteins $(1,2,4-7,10,11,14$, $19,23-25,30-33$, and 35-37) and downregulated 17 proteins $(3,8,9,12,13,15-18,20-22,26-29$, and 34) under droughtstress conditions while 20 proteins $(1,4-7,10-12,14,23-25$, and 30-37) were upregulated and 17 proteins $(2,3,8,9,13,15-$ 22 , and 26-29) were downregulated under ambient $\mathrm{CO}_{2}$ concentration following drought-stress treatment (Figs. 5, 6A and $\mathrm{B}$ ). Moreover, the fold change in abundance was significantly different between elevated $\mathrm{CO}_{2}$ well-irrigated and elevated $\mathrm{CO}_{2}$ drought-stress treatments for 24 proteins $(2,3$, $7,8,10,13-15,17-26,29,30,32$, and 35-37), between ambient $\mathrm{CO}_{2}$ drought stress and elevated $\mathrm{CO}_{2}$ drought-stress treatments for 22 proteins $(1,2,4,8-13,15,16,19,21,27-29$, and 32-37), and among all three treatments for 11 proteins $(2,8,10,13,15$, 19, 21, 29, 32, 35, and 36) (Figs. 5, 6A and B). The biological functions of those proteins with upregulated or downregulated abundance by elevated $\mathrm{CO}_{2}$ are discussed, with an emphasis on several notable proteins regulated by elevated $\mathrm{CO}_{2}$, which may contribute to $\mathrm{CO}_{2}$ mitigation of drought-stress damages in creeping bentgrass.
The majority of soluble proteins responding to elevated $\mathrm{CO}_{2}$ with or without drought stress were involved in energy metabolism in creeping bentgrass leaves. Elevated $\mathrm{CO}_{2}$ increased the abundance of several major proteins involved in the Calvin-Benson cycle including fructose bisphosphate aldolase precursor (FBA), chloroplastic GAPDH-A, and chloroplastic sedoheptulose bisphosphatase precursor (SBPase) under well-irrigated and drought conditions. The drought-induced decrease in $\mathrm{RuBisCO}$ abundance was less severe due to elevated $\mathrm{CO}_{2}$ compared with ambient $\mathrm{CO}_{2}$. The drought-induced increase in cytosolic GAPDH abundance contributing to respiratory glycolytic breakdown of glucose was less severe due to elevated $\mathrm{CO}_{2}$ compared with ambient $\mathrm{CO}_{2}$. Our results suggest that the enhanced drought tolerance observed in creeping bentgrass under drought stress may be in part due to changes in abundance for those proteins regulating key energy functions within leaf tissues and are discussed in detail below.

FBA catalyzes the sixth reaction of the Calvin-Benson cycle converting fructose 1,6-bisphosphate to glyceraldehyde 3-phosphate yielding dihydroxyacetone phosphate and ATP and has been shown to have direct effects on the regeneration rate ribulose-1,5bisphosphate (RuBP) for carbon fixation (Iwaki et al., 1991; Taiz and Zeiger, 2010). Research describing changes in FBA abundance responding to abiotic stresses is limited, although Abbasi and Komatsu (2004) reported FBA abundance was upregulated in rice (Oryza sativa) leaf sheaths during salinity stress, while gene transcript level analysis revealed differential responses of eight FBA genes in Arabidopsis thaliana shoots responding to chilling, heat, or drought stress (Lu et al., 2012). Leaf FBA content at the transcript and protein level significantly increased due to elevated $\mathrm{CO}_{2}$ treatment for rice under nonstress conditions and tall fescue under heat-stress conditions (Fukayama et al., 2009; Yu et al., 2014). In this study, FBA abundance increased by 1.0- and 1.1-fold due to elevated $\mathrm{CO}_{2}$ under well-irrigated conditions and drought stress, respectively, but increased by 2.3 -fold due to drought stress under ambient $\mathrm{CO}_{2}$ concentration. The regulation of FBA abundance under elevated $\mathrm{CO}_{2}$ suggested that elevated $\mathrm{CO}_{2}$ could sustain constant ATP production and RuBP regeneration rates supporting plant growth during drought periods.

Chloroplastic GAPDH is composed of A and B subunits, which catalyze the nicotinamide adenine dinucleotide phosphateconsuming reduction of 1,3-bisphosphoglycerate to glyceraldehyde 3-phosphate during the reduction phase of the Calvin-Benson cycle (Sparla et al., 2005; Taiz and Zeiger, 2010). In a manner similar to FBA limitation, plants with decreased chloroplastic GAPDH abundance may experience reduced $\mathrm{CO}_{2}$ assimilation due to a reduction in RuBP regeneration, which can then cause subsequent declines in photosynthetic rates and net biomass accumulation (Price et al., 1995). Abiotic stresses such as drought cause significant decreases in chloroplastic GAPDH abundance whereas plants with increased stress tolerance typically exhibit greater abundance of chloroplastic 
Table 1. Creeping bentgrass leaf soluble proteins differentially accumulated following exposure to ambient $\left(400 \mu \mathrm{L} \cdot \mathrm{L}^{-1}\right)$ or elevated $\left(800 \mu \mathrm{L} \cdot \mathrm{L}^{-1}\right)$ $\mathrm{CO}_{2}$ concentration for $35 \mathrm{~d}$ followed by well-irrigated or drought-stress conditions for $21 \mathrm{~d}$. Spot numbers correspond to highlighted proteins in Fig. 3.

\begin{tabular}{|c|c|c|c|c|c|}
\hline$\overline{\text { Functional category }}$ & Spot no. & Protein name & Abbreviation & Accession no. & $\mathrm{MW} / \mathrm{PI}$ \\
\hline \multirow[t]{25}{*}{ Energy } & 1 & $\begin{array}{l}\text { Glyceraldehyde-3-phosphate dehydrogenase, } \\
\text { cytosolic }\end{array}$ & GAPDH & 120668 & $33.2 / 6.20$ \\
\hline & 2 & $\begin{array}{l}\text { Glyceraldehyde-3-phosphate dehydrogenase } \\
\text { A, chloroplastic }\end{array}$ & GAPDH-A & 115458768 & $42.7 / 7.62$ \\
\hline & 3 & $\begin{array}{l}\text { Fructose } 1,6 \text {-bisphosphate } \\
\text { aldolase, cytoplasmic isozyme }\end{array}$ & FBA (cyt) & 115468886 & $37.7 / 7.57$ \\
\hline & 4 & Fructose 1,6-bisphosphate aldolase precursor & FBA & 8272480 & $41.9 / 9.01$ \\
\hline & 5 & Triosephosphate isomerase, cytosolic & TIM & 2507469 & $26.79 / 5.39$ \\
\hline & 6 & Cytoplasmic aldolase & Cyt. ald. & 218157 & $38.7 / 6.56$ \\
\hline & 7 & Phosphoglycerate mutase & PGAM & 32400802 & $29.6 / 5.43$ \\
\hline & 8 & Rubisco activase beta form precursor & $\mathrm{RCA} \beta$ & 32481063 & $47.1 / 7.57$ \\
\hline & 9 & Ribulose 1,5-bisphosphate carboxylase & $\mathrm{RuBisCO}$ & 1488586 & $45.3 / 6.28$ \\
\hline & 10 & $\begin{array}{l}\text { Ribulose-5-phosphate 3-epimerase, } \\
\text { chloroplast precursor }\end{array}$ & R5P3E & 2833386 & $30.3 / 8.23$ \\
\hline & 11 & $\begin{array}{l}\text { Sedoheptulose-1,7-bisphosphatase, } \\
\text { chloroplast precursor }\end{array}$ & SBPase & 1173347 & $42 / 6.04$ \\
\hline & 12 & $\begin{array}{l}\text { Ferredoxin-NADP+ reductase, chloroplastic } \\
\text { isozyme }\end{array}$ & FNR & 115443657 & $38.7 / 7.98$ \\
\hline & 13 & $\begin{array}{l}\text { Crystal structure complex between ferredoxin } \\
\text { and ferredoxin NADP+ reductase }\end{array}$ & FDI-FNR & 13096165 & $35.3 / 7.01$ \\
\hline & 14 & ATP synthase F1 sector beta subunit & ATPF1 $\beta$ & 50401827 & $53.8 / 5.17$ \\
\hline & 15 & ATP synthase CF1 alpha subunit & ATPCF1 $\alpha$ & 14017569 & $55.3 / 6.11$ \\
\hline & 16 & ATP synthase alpha subunit & ATP $\alpha$ & 51556908 & $55.5 / 6.03$ \\
\hline & 17 & Oxygen-evolving complex protein 1 & OEE1 & 739292 & $26.5 / 5.13$ \\
\hline & 18 & $\begin{array}{l}\text { Oxygen-evolving enhancer protein } 2 \text {, } \\
\text { chloroplast precursor }\end{array}$ & OEE2 & 131394 & $27.3 / 8.84$ \\
\hline & 19 & $\begin{array}{l}\text { HCF136 photosystem II stability/assembly } \\
\text { factor, chloroplast precursor }\end{array}$ & HCF136 & 75252730 & $45.4 / 9.02$ \\
\hline & 20 & PSI type III chlorophyll a/b-binding protein & PSI a/b & 430947 & $29.1 / 8.61$ \\
\hline & 21 & Light-harvesting complex I & LHC1 & 544700 & $24.2 / 8.11$ \\
\hline & 22 & Carbonic anhydrase, chloroplast precursor & $\mathrm{CAH}$ & 729003 & $35.1 / 8.93$ \\
\hline & 23 & Malate dehydrogenase & $\mathrm{MDH}$ & 10798652 & $35.4 / 5.91$ \\
\hline & 24 & $\begin{array}{l}\text { Dihydrolipoyl dehydrogenase-1, } \\
\text { mitochondrial isoform }\end{array}$ & DLD & 115436320 & $52.6 / 7.21$ \\
\hline & 25 & $\begin{array}{l}\text { Glycerate dehydrogenase HPR, } \\
\text { peroxisomal }\end{array}$ & HPR & 115443619 & $42 / 6.56$ \\
\hline \multirow[t]{3}{*}{ Stress defense } & 26 & Thioredoxin peroxidase & TPX & 3328221 & $28.1 / 6.34$ \\
\hline & 27 & Catalase-1 & CAT & 2493543 & $56.8 / 6.52$ \\
\hline & 28 & Heat shock protein 70 & HSP70 & 1143427 & $75.4 / 5.15$ \\
\hline \multirow[t]{6}{*}{ Metabolism } & 29 & Alpha-glucan phosphorylase, H-isozyme & AGP & 14916632 & $93.6 / 7.27$ \\
\hline & 30 & $\begin{array}{l}\text { Glutamate-ammonia ligase, chloroplast } \\
\text { precursor }\end{array}$ & GAL & 121340 & $47.1 / 5.11$ \\
\hline & 31 & Aspartate carbamoyltransferase & ACT & 21535795 & $42.6 / 6.06$ \\
\hline & 32 & Phosphoribulokinase & PRK & 21839 & $45 / 5.84$ \\
\hline & 33 & Aminomethyltransferase, mitochondrial & AMT & 115460656 & $43.9 / 8.53$ \\
\hline & 34 & Methionine synthase & MS & 50897038 & $84.5 / 5.68$ \\
\hline \multirow{2}{*}{$\begin{array}{l}\text { Protein destination } \\
\text { and storage }\end{array}$} & 35 & PFTF precursor, FTSH-like & PFTF & 52075838 & $72.5 / 5.54$ \\
\hline & 36 & Protein disulfide isomerase 2 precursor & PDIM & 13925726 & $56.4 / 5.03$ \\
\hline Protein synthesis & 37 & Tu translational elongation factor & $\mathrm{EF}-\mathrm{Tu}$ & 17225494 & $50.4 / 6.19$ \\
\hline
\end{tabular}

$\overline{\mathrm{MW}}=$ molecular weight in kilodaltons; $\mathrm{PI}=$ isoelectric point; NADP $=$ nicotinamide adenine dinucleotide phosphate; ATP $=$ adenosine triphosphate; HCF = high chlorophyll fluorescence; PSI = photosystem I.

GAPDH compared with stress-sensitive plants (Merewitz et al., 2011; Xu and Huang, 2010a, 2010b). Reports on elevated $\mathrm{CO}_{2}$ regulation of chloroplastic GAPDH abundance are limited and vary across different plant species and different stress conditions. Yu et al. (2014) reported that the abundance of chloroplastic GADPH decreased due to elevated $\mathrm{CO}_{2}$ under nonstress conditions but did not change due to elevated $\mathrm{CO}_{2}$ following heat-stress treatment in tall fescue. Furthermore, chloroplastic GAPDH enzyme activity was either significantly increased or relatively unchanged due to elevated $\mathrm{CO}_{2}$ under 


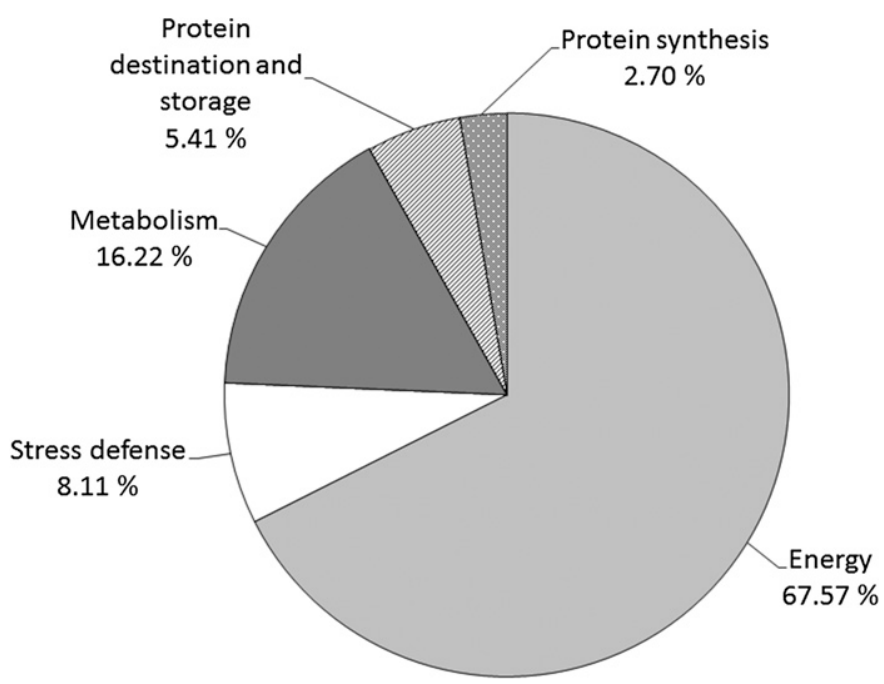

Fig. 4. Functional classification and percent of proteins with differential responses in abundance in creeping bentgrass leaves following exposure to ambient $\left(400 \mu \mathrm{L} \cdot \mathrm{L}^{-1}\right)$ or elevated $\left(800 \mu \mathrm{L} \cdot \mathrm{L}^{-1}\right) \mathrm{CO}_{2}$ concentration for $35 \mathrm{~d}$ followed by well-irrigated or drought-stress conditions for $21 \mathrm{~d}$.

nonstress conditions in other plant species (Haake et al., 1999; Ribeiro et al., 2012; Zhang et al., 2005). In this study, chloroplastic GAPDH abundance increased by 2.2- and 1.7fold due to elevated $\mathrm{CO}_{2}$ under well-irrigated conditions and drought stress, respectively, and was significantly greater during drought stress under elevated $\mathrm{CO}_{2}$ compared with ambient $\mathrm{CO}_{2}$ concentration (Fig. 6A). The observed changes in GAPDH abundance indicated that elevated $\mathrm{CO}_{2}$ treatment effectively mitigated the decrease in chloroplastic GAPDH abundance upon prolonged drought stress. The ability of elevated $\mathrm{CO}_{2}$ to alleviate the decline in chloroplastic GAPDH abundance may aide in RuBP regeneration and a continuation of $\mathrm{CO}_{2}$ assimilation driving photosynthesis during droughtstress periods.

$\mathrm{RuBisCO}$ is the most abundant soluble protein responsible for catalyzing the first step of the Calvin-Benson cycle, reacting $\mathrm{CO}_{2}$ and water with RuBP yielding 3-phosphoglycerate (Cleland et al., 1998). Abiotic stresses such as drought impose metabolic limitations on photosynthesis by reducing net abundance of large and small RuBisCO subunits concurrent with inhibition of RuBisCO activation state, among many other biochemical changes (Huang et al., 2014; Shi et al., 2013). Grass species displaying improved tolerance to various abiotic stresses by means of endogenous or exogenous modification typically maintain sufficient RuBisCO abundance or mitigate the extent of decline in RuBisCO abundance (Jespersen et al., 2015; Xu and Huang, 2012b, 2010c; Zhao et al., 2011). It is well accepted that a key component of photosynthetic acclimation to long-term elevated $\mathrm{CO}_{2}$ treatment is a substantial decrease in $\mathrm{RuBisCO}$ both at the transcript and protein level associated with disproportionate resource allocation favoring RuBP regeneration (Bowes, 1991; Feng et al., 2014; Ziska and Teramura, 1992). The stress-mitigating effects of elevated $\mathrm{CO}_{2}$ facilitated by changes to photosynthetic constituents have been well described for a number of plant species under various abiotic stresses (Alonso et al., 2009; Huang and $\mathrm{Xu}, 2015$ ). Vu et al. (1998) reported that the decline in RuBisCO abundance and activity was significantly less for drought-stressed rice plants grown at elevated $\mathrm{CO}_{2}$ compared with those at ambient $\mathrm{CO}_{2}$ and similar effects were also reported with regard to RuBisCO enzyme activity in sugarcane (Saccharum officinarum) under drought stress ( $\mathrm{Vu}$ and Allen, 2009). In this study, RuBisCO abundance decreased by 1.1 - and 1.5 -fold due to elevated $\mathrm{CO}_{2}$ under well-irrigated conditions and drought stress, respectively, and the decrease was significantly less during drought stress under elevated $\mathrm{CO}_{2}$ compared with ambient $\mathrm{CO}_{2}$ concentration (Fig. 6A). Decreased RuBisCO abundance by elevated $\mathrm{CO}_{2}$ may lead to suppression of photorespiration in cool-season plants (Ehleringer et al., 1991), which could help to avoid inefficient oxygenation of RuBP.

Chloroplastic SBPase is the second bisphosphatase enzyme of the Calvin-Benson cycle, the first being fructose 1,6bisphosphatase, and is responsible for catalyzing sedoheptulose 1,7-bisphosphate dephosphorylation to sedoheptulose7-phosphate during the regeneration phase (Raines et al., 1999). Research using transgenic antisense tobacco (Nicotiana tabacum) lines has suggested a direct link between SBPase content and capacity for RuBP regeneration and subsequent carbon assimilation (Harrison et al., 1998, 2001). Despite the crucial role of SBPase in plant energy metabolism, there exists far less information regarding effects of abiotic stresses on SBPase abundance. In a review by Kosová et al. (2011), it was reported that SBPase abundance was downregulated in rice subjected to ozone stress but upregulated in poplar (Populus euphratica) tolerant of heavy metal hyperaccumulation. Transgenic rice overexpressing and accumulating SBPase prevented RuBisCO activase sequestration thereby maintaining sufficient $\mathrm{RuBisCO}$ activation for improved tolerance to heat stress (Feng et al., 2007). More specifically, SBPase abundance is significantly downregulated in creeping bentgrass and kentucky bluegrass upon drought stress but the downregulation was significantly less for drought-tolerant cultivars of each species $(\mathrm{Xu}$ and Huang 2010a, 2010c). Similar effects were also noted in creeping bentgrass lines expressing differential tolerance to heat stress (Xu and Huang, 2010b). Given that SBPase is another limiting factor of RuBP regeneration, tobacco plants overexpressing SBPase displayed increased photosynthesis and biomass accumulation when grown at elevated $\mathrm{CO}_{2}$ compared with plants at ambient $\mathrm{CO}_{2}$ (Rosenthal et al., 2011). However, the direct effects of elevated $\mathrm{CO}_{2}$ on $\mathrm{SBPase}$ protein abundance and transcript level are variable based on plant species and possible interacting stress effects. SBPase transcript level increased in rice plants exposed to elevated $\mathrm{CO}_{2}$ across varied nitrogen fertility regimens, but decreased due to high $\mathrm{CO}_{2}$ when soil temperature was increased above the optimal range (Fukayama et al., 2009, 2011). Protein abundance and transcript levels of SBPase remained unaffected in durum wheat (Triticum durum) exposed to elevated $\mathrm{CO}_{2}$ under nonstress conditions and similar results were also reported for perennial ryegrass (Lolium perenne) protein abundance (Aranjuelo et al., 2013; Nie et al., 1995; Rogers et al., 1998). In this study, SBPase protein abundance increased by 1.1 - and 1.0 -fold due to elevated $\mathrm{CO}_{2}$ under well-irrigated conditions and drought stress, respectively (Fig. 6A). The response in SBPase abundance was similar to that of FBA, likely because condensation of SBPase and fructose 1,6bisphosphatase are both catalyzed by FBA in the CalvinBenson cycle (Lu et al., 2012). The results suggest that ATP production and $\mathrm{RuBP}$ regeneration rates may be supported by 


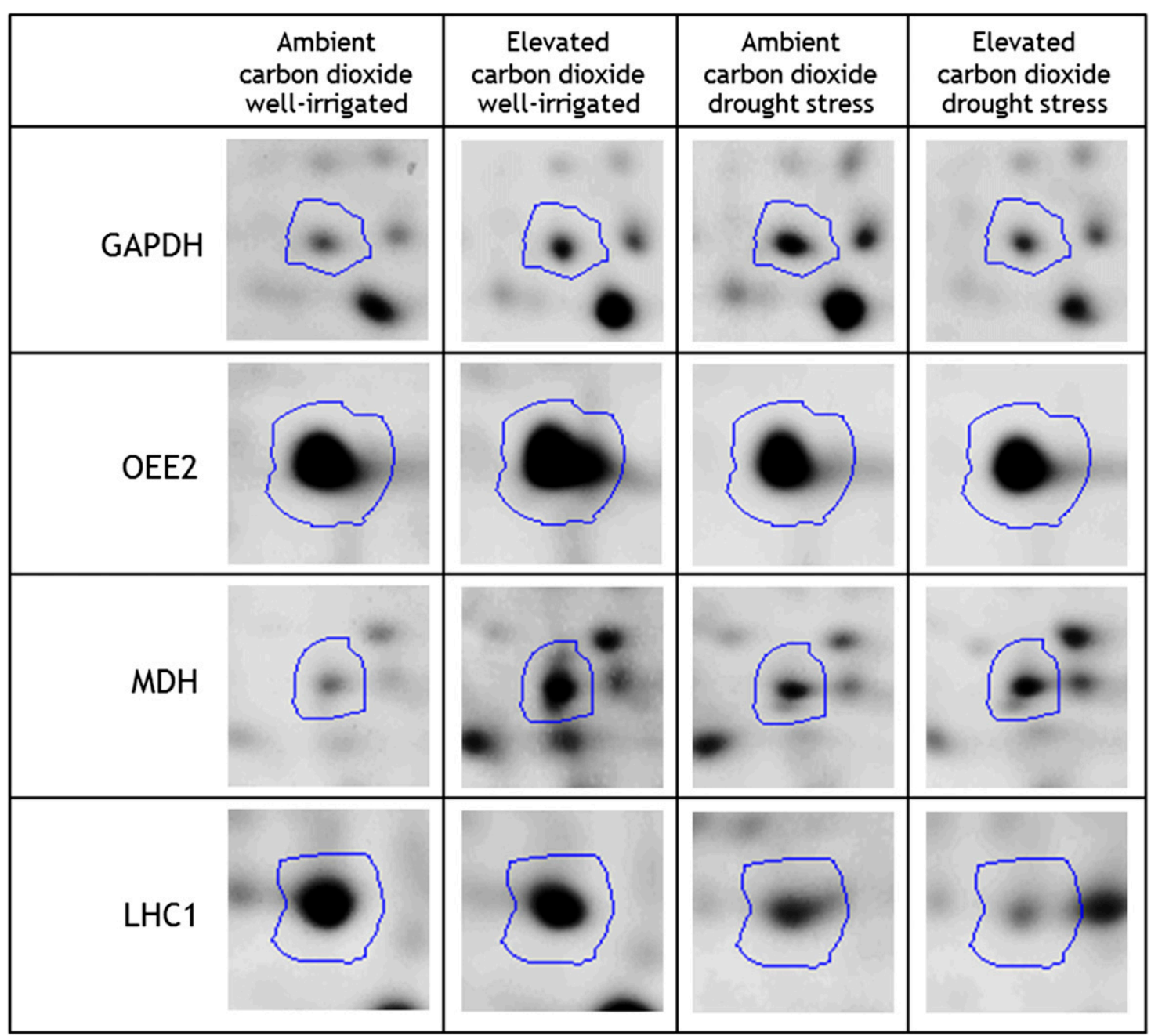

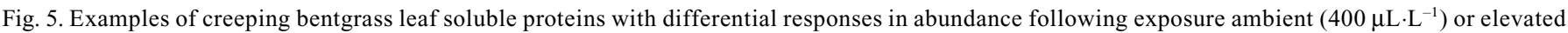
$\left(800 \mu \mathrm{L} \cdot \mathrm{L}^{-1}\right) \mathrm{CO}_{2}$ concentration for $35 \mathrm{~d}$ followed by well-irrigated or drought-stress conditions for $21 \mathrm{~d}$. GAPDH $=$ cytosolic glyceraldehyde-3phosphate dehydrogenase; LHC1 = light-harvesting complex I; MDH = malate dehydrogenase; OEE2 = oxygen-evolving enhancer protein 2, chloroplast precursor.

increased FBA abundance and further sustain plant growth during drought periods.

Cytosolic GAPDH catalyzes the sixth step of glycolysis by oxidizing aldehyde to carboxylic acid releasing energy to phosphorylate glyceraldehyde 3-phosphate into 1,3-bisphosphoglycerate in the presence of nicotinamide adenine dinucleotide and inorganic phosphate (Ramzan et al., 2013; Taiz and Zeiger, 2010). Abiotic stresses including heat, drought, or anoxic conditions have been shown to significantly increase cytosolic GAPDH abundance, which maintains glycolytic breakdown of carbohydrates for energy production and suppresses the production of inhibitory ROS (Chang et al., 2000; Ferreira et al., 2006; Xu and Huang, 2012b; Yang et al., 1993). However, increasing or maintaining the abundance of glycolytic chemical constituents driving respiration can promote whole-plant stress tolerance only when photosynthetic carbon input equals or exceeds respiratory carbon consumption (Song et al., 2014). A review of plant proteomic changes under abiotic stresses showed that excessive abundance of cytosolic GAPDH is typically associated with susceptibility to abiotic stresses such as drought, waterlogging, and hypoxia/anoxia
(Kosová et al., 2011). In this study, cytosolic GAPDH protein abundance increased by 3.2- and 3.4-fold due to elevated $\mathrm{CO}_{2}$ under well-irrigated conditions and drought stress, respectively, and the increase was significantly less under drought due to elevated $\mathrm{CO}_{2}$ compared with ambient $\mathrm{CO}_{2}$ concentration (Figs. 5 and 6A). Elevated $\mathrm{CO}_{2}$ effectively maintained an increased abundance of cytosolic GAPDH content under drought-stress conditions, which may sustain energy production while avoiding a potential excess of cytosolic GAPDH abundance observed during drought stress under ambient $\mathrm{CO}_{2}$ concentrations.

In summary, this study suggests beneficial effects of elevated $\mathrm{CO}_{2}$ for lessening the drought damages and improving physiological functions in creeping bentgrass potentially facilitated by changes in protein abundance supporting energy metabolism of leaves in creeping bentgrass. Elevated $\mathrm{CO}_{2}$ improved creeping bentgrass growth by maintaining leaf hydration and membrane integrity, which may be in part a result of changes in abundance for proteins of the CalvinBenson cycle including FBA precursor, chloroplastic GAPDH-A, RuBisCO, and chloroplastic SBPase precursor. 

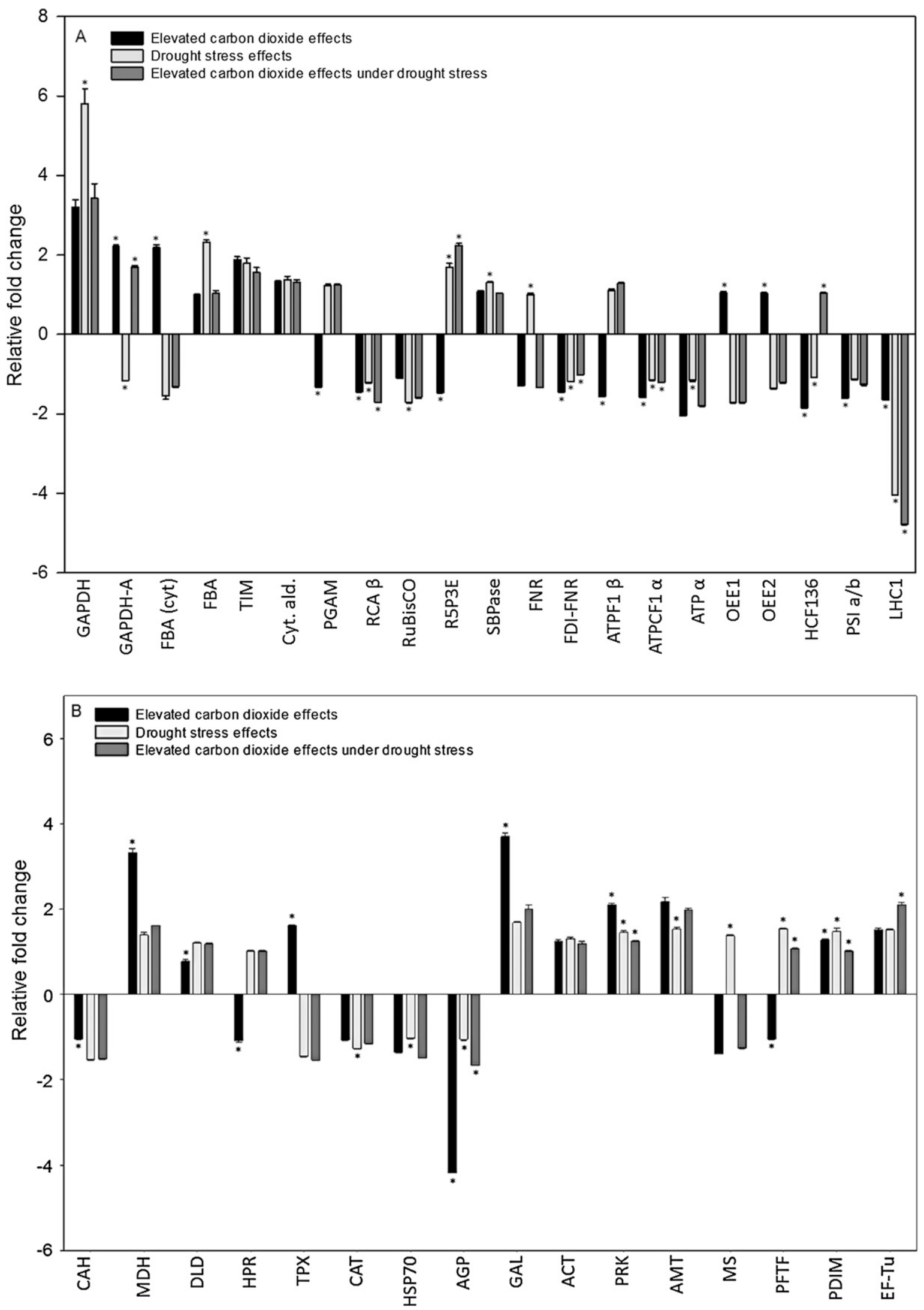

Fig. 6. (A and B) Fold changes in soluble protein abundance in creeping bentgrass leaves following exposure to ambient $\left(400 \mu \mathrm{L} \cdot \mathrm{L}^{-1}\right)$ or elevated $\left(800 \mu \mathrm{L} \cdot \mathrm{L}^{-1}\right) \mathrm{CO}{ }_{2}$ concentration for $35 \mathrm{~d}$ followed by well-irrigated or drought-stress conditions for $21 \mathrm{~d}$ relative to ambient $\mathrm{CO}_{2}$ well-irrigated control treatment. Positive data indicate increases in protein abundance or upregulation and negative data indicate decreases in protein abundance or downregulation. Only those proteins who had significantly altered accumulations compared with ambient $\mathrm{CO}_{2}$ well-irrigated control treatment are represented in the figure $(\alpha=0.05)$. Vertical lines atop bars represent SE of five replicates for each treatment and asterisks atop bars indicate significant differences between treatments exist according to Fisher's least significant difference test $(\alpha=0.05)$. Protein abbreviations correspond with respective protein information provided in Table 1. 
Elevated $\mathrm{CO}_{2}$ also decreased cytosolic GAPDH abundance during drought, which may have downstream effects on certain aspects of plant respiration. Further research is needed to confirm the biological functions and associated molecular factors of $\mathrm{CO}_{2}$-responsive proteins identified in this study contributing to improved drought tolerance in cool-season grass species.

\section{Literature Cited}

Abbasi, F.M. and S. Komatsu. 2004. A proteomic approach to analyze salt-responsive proteins in rice leaf sheaths. Proteomics 4:20722081.

Ainsworth, E.A., P.A. Davey, C.J. Bernacchi, O.C. Dermody, E.A. Heaton, D.J. Moore, P.B. Morgan, S.L. Naidu, H.Y. Ra, X. Zhu, P.S. Curtis, and S.P. Long. 2002. A meta-analysis of elevated $\left[\mathrm{CO}_{2}\right]$ effects on soybean (Glycine $\max$ ) physiology, growth and yield. Glob. Change Biol. 8:695-709.

Alonso, A., P. Pérez, and R. Martínez-Carrasco. 2009. Growth in elevated $\mathrm{CO}_{2}$ enhances temperature response of photosynthesis in wheat. Physiol. Plant. 135:109-120.

Aranjuelo, I., Á. Sanz-Sáez, I. Jauregui, J.J. Irigoyen, J.L. Araus, M. Sánchez-Díaz, and G. Erice. 2013. Harvest index, a parameter conditioning responsiveness of wheat plants to elevated $\mathrm{CO}_{2}$. J. Expt. Bot. 64:1879-1892.

Aroca, R. 2012. Plant responses to drought stress, from morphological to molecular features. Springer-Verlag, Berlin/Heidelberg, Germany.

Barrs, H.D. and P.E. Weatherley. 1962. A re-examination of the relative turgidity technique for estimating water deficits in leaves. Austral. J. Biol. Sci. 15:413-428.

Beard, J.B. 1973. Turfgrass: Science and culture. Prentice Hall, Englewood Cliffs, NJ.

Bevan, M., I. Bancroft, E. Bent, K. Love, H. Goodman, C. Dean, R. Bergkamp, W. Dirkse, M. Van Staveren, W. Stiekema, L. Drost, P. Ridley, S.-A. Hudson, K. Patel, G. Murphy, P. Piffanelli, H. Wedler, E. Wedler, R. Wambutt, T. Weitzenegger, T.M. Pohl, N. Terryn, J. Gielen, R. Villarroel, R. De Clerck, M. Van Montagu, A. Lecharny, S. Auborg, I. Gy, M. Kreis, N. Lao, T. Kavanagh, S. Hempel, P. Kotter, K.-D. Entian, M. Rieger, M. Schaeffer, B. Funk, S. MuellerAuer, M. Silvey, R. James, A. Montfort, A. Pons, P. Puigdomenech, A. Douka, E. Voukelatou, D. Milioni, P. Hatzopoulos, E. Piravandi, B. Obermaier, H. Hilbert, A. Düsterhöft, T. Moores, J.D.G. Jones, T. Eneva, K. Palme, V. Benes, S. Rechman, W. Ansorge, R. Cooke, C. Berger, M. Delseny, M. Voet, G. Volckaert, H.-W. Mewes, S. Klosterman, C. Schueller, and N. Chalwatzis. 1998. Analysis of 1.9 $\mathrm{Mb}$ of contiguous sequence from chromosome 4 of Arabidopsis thaliana. Nature 391:485-488.

Blum, A. and A. Ebercon. 1981. Cell membrane stability as a measure of drought and heat tolerance in wheat. Crop Sci. 21:43-47.

Bowes, G. 1991. Growth at elevated $\mathrm{CO}_{2}$ : Photosynthetic responses mediated through Rubisco. Plant Cell Environ. 14:795-806.

Bradford, M.M. 1976. A rapid and sensitive method for the quantitation of microgram quantities of protein utilizing the principle of protein-dye-binding. Anal. Biochem. 72:248-254.

Burgess, P. and B. Huang. 2014. Root protein metabolism in association with improved root growth and drought tolerance by elevated carbon dioxide in creeping bentgrass. Field Crops Res. 165:80-91.

Ceulemans, R. and M. Mousseau. 1994. Effects of elevated atmospheric $\mathrm{CO}_{2}$ on woody plants. Tansley Review No. 71. New Phytol. 127:425-446.

Chang, W.W.P., L. Huang, M. Shen, C. Webster, A.L. Burlingame, and J.K.M. Roberts. 2000. Patterns of protein synthesis and tolerance of anoxia in root tips of maize seedlings acclimated to a low-oxygen environment and identification of proteins by mass spectrometry. Plant Physiol. 122:295-318.
Cleland, W.W., T.J. Andrews, S. Gutteridge, F.C. Hartman, and G.H. Lorimer. 1998. Mechanism of Rubisco: The carbamate as general base. Chem. Rev. 98:549-562.

Ehleringer, J.R., R.F. Sage, L.B. Flanagan, and R.W. Pearcy. 1991. Climate change and the evolution of $\mathrm{C} 4$ photosynthesis. Trends Ecol. Evol. 6:95-99.

Feng, L., K. Wang, Y. Li, Y. Tan, J. Kong, H. Li, Y. Li, and Y. Zhu. 2007. Overexpression of SBPase enhances photosynthesis against high temperature stress in transgenic rice plants. Plant Cell Rpt. 26:1635-1646.

Feng, G.-Q., Y. Li, and Z.-M. Cheng. 2014. Plant molecular and genomic responses to stresses in projected future $\mathrm{CO}_{2}$ environment. Crit. Rev. Plant Sci. 33:238-249.

Ferreira, S., K. Hjernø, M. Larsen, G. Wingsle, P. Larsen, S. Fey, P. Roepstorff, and M.S. Pais. 2006. Proteome profiling of Populus euphratica Oliv. upon heat stress. Ann. Bot. 98:361-377.

Fukayama, H., T. Fukuda, C. Masumoto, Y. Taniguchi, H. Sakai, W. Cheng, T. Hasegawa, and M. Miyao. 2009. Rice plant response to long term $\mathrm{CO}_{2}$ enrichment, gene expression profiling. Plant Sci. 177:203-210.

Fukayama, H., M. Sugino, T. Fukuda, C. Masumoto, Y. Taniguchi, M. Okada, R. Sameshima, T. Hatanaka, S. Misoo, T. Hasegawa, and M. Miyao. 2011. Gene expression profiling of rice grown in free air $\mathrm{CO}_{2}$ enrichment (FACE) and elevated soil temperature. Field Crops Res. 121:195-199.

Haake, V., M. Geiger, P. Walch-Liu, C. Engels, R. Zrenner, and M. Stitt. 1999. Changes in aldolase activity in wild-type potato plants are important for acclimation to growth irradiance and carbon dioxide concentration because plastid aldolase exerts control over the ambient rate of photosynthesis across a range of growth conditions. Plant J. 17:479-489.

Harrison, E.P., N.M. Willingham, J.C. Lloyd, and C.A. Raines. 1998. Reduced sedoheptulose-1,7-bisphosphatase levels in transgenic tobacco lead to decreased photosynthetic capacity and altered carbohydrate accumulation. Planta 204:27-36.

Harrison, E.P., H. Olcer, J.C. Lloyd, S.P. Long, and C.A. Raines. 2001. Small decreases in SBPase cause a linear decline in the apparent RuBP regeneration rate, but do not affect Rubisco carboxylation capacity. J. Expt. Bot. 52:1779-1784.

Hoagland, D.R. and D. Arnon. 1950. The water-culture method for growing plants without soil. 2nd ed. California Agr. Expt. Sta. Circ. 347.

Huang, B. and Y. Xu. 2015. Cellular and molecular mechanisms for elevated $\mathrm{CO}_{2}$-regulation of plant growth and stress adaptation. Crop Sci. 55:1405-1425.

Huang, B., M. DaCosta, and Y. Jiang. 2014. Research advances in mechanisms of turfgrass tolerance to abiotic stresses, from physiology to molecular biology. Crit. Rev. Plant Sci. 33:141189.

Iwaki, T., A. Wadano, A. Yokota, and M. Himeno. 1991. Aldolase, an important enzyme in controlling the ribulose 1,5-bisphosphate regeneration rate in photosynthesis. Plant Cell Physiol. 32:10831091 .

Jambunathan, N. 2010. Determination and detection of reactive oxygen species (ROS), lipid peroxidation, and electrolyte leakage in plants, p. 291-297. In: R. Sunkar (ed.). Plant stress tolerance, methods in molecular biology 639. Humana Press, New York, NY.

Jespersen, D., W. Meyer, and B. Huang. 2013. Physiological traits and genetic variations associated with drought and heat tolerance in creeping bentgrass. Intl. Turfgrass Res. J. 12:459-464.

Jespersen, D., C. Xu, and B. Huang. 2015. Membrane proteins associated with heat-induced leaf senescence in a cool-season grass species. Crop Sci. 55:837-850.

Kirkham, M.B. 2011. Elevated atmospheric carbon dioxide, $\mathrm{C}_{3}$ and $\mathrm{C}_{4}$ plants, p. 247-266. In: M.B. Kirkham (ed.). Elevated carbon dioxide, impact on soil and plant water relations. CRC Press, Boca Raton, FL. 
Kopp, K.L. and Y. Jiang. 2013. Turfgrass water use and physiology, p. 319-345. In: J.C. Stier, B. Horgan, and S.A. Bonos (eds.). Turfgrass: Biology, use, and management. Amer. Soc. Agr., Crop Sci. Soc. Amer., Soil Sci. Soc. Amer., Madison, WI.

Kosová, K., P. Vítámvás, I.T. Prášil, and J. Renaut. 2011. Plant proteome changes under abiotic stress, contribution of proteomics studies to understanding plant stress response. J. Proteomics 74:1301-1322.

Leakey, A.D.B., E.A. Ainsworth, C.J. Bernacchi, A. Rogers, S.P. Long, and D.R. Ort. 2009. Elevated $\mathrm{CO}_{2}$ effects on plant carbon, nitrogen, and water relations: Six important lessons from FACE. J. Expt. Bot. 60:2859-2876.

Lin, J.-S. and G.-X. Wang. 2002. Doubled $\mathrm{CO}_{2}$ could improve the drought tolerance better in sensitive cultivars than in tolerant cultivars in spring wheat. Plant Sci. 163:627-637.

Lu, W., X. Tang, Y. Huo, R. Xu, S. Qi, J. Huang, C. Zheng, and C. Wu. 2012. Identification and characterization of fructose 1,6-bisphosphate aldolase genes in Arabidopsis reveals a gene family with diverse responses to abiotic stresses. Gene 503:65-74.

Merewitz, E.B., T. Gianfagna, and B. Huang. 2011. Protein accumulation in leaves and roots associated with improved drought tolerance in creeping bentgrass expressing an ipt gene for cytokinin synthesis. J. Expt. Bot. 62:5311-5333.

Neuhoff, V., N. Arold, D. Taube, and W. Ehrhardt. 1988. Improved staining of proteins in polyacrylamide gels including isoelectric focusing gels with clear background at nanogram sensitivity using Coomassie Brilliant Blue G-250 and R-250. Electrophoresis 9:255262.

Nie, G., D.L. Hendrix, A.N. Webber, B.A. Kimball, and S.P. Long. 1995. Increased accumulation of carbohydrates and decreased photosynthetic gene transcript levels in wheat grown at an elevated $\mathrm{CO}_{2}$ concentration in the field. Plant Physiol. 108:975983.

Pérez-López, U., A. Robredo, M. Lacuesta, C. Sgherri, A. MuñozRueda, F. Navari-Izzo, and A. Mena-Petite. 2009. The oxidative stress caused by salinity in two barley cultivars is mitigated by elevated $\mathrm{CO}_{2}$. Physiol. Plant. 135:29-42.

Peterson, A.G., J.T. Ball, Y. Luo, C.B. Field, P.B. Reich, P.S. Curtis, K.L. Griffin, C.A. Gunderson, R.J. Norby, D.T. Tissue, M. Forstreuter, A. Rey, and C.S. Vogel. . CMEAL participants. 1999. The photosynthesis-leaf nitrogen relationship at ambient and elevated atmospheric carbon dioxide: A meta-analysis. Glob. Change Biol. 5:331-346.

Price, G.D., J.R. Evans, S. von Caemmerer, J.-W. Yu, and M.R. Badger. 1995. Specific reduction of chloroplast glyceraldehyde-3phosphate dehydrogenase activity by antisense RNA reduces $\mathrm{CO}_{2}$ assimilation via a reduction in ribulose bisphosphate regeneration in transgenic tobacco plants. Planta 195:369-378.

Qaderi, M.M., L.V. Kurepin, and D.M. Reid. 2006. Growth and physiological responses of canola (Brassica napus) to three components of global climate change: Temperature, carbon dioxide and drought. Physiol. Plant. 128:710-721.

Raines, C.A., J.C. Lloyd, and T.A. Dyer. 1999. New insights into the structure and function of sedoheptulose-1,7-bisphosphatase: An important but neglected Calvin cycle enzyme. J. Expt. Bot. 50:1-8.

Ramzan, R., P. Weber, U. Linne, and S. Vogt. 2013. GAPDH: The missing link between glycolysis and mitochondrial oxidative phosphorylation. Biochem. Soc. Trans. 41:1294-1297.

Ribeiro, D.M., W.L. Araújo, A.R. Fernie, J.H.M. Schippers, and B. Mueller-Roeber. 2012. Action of gibberellins on growth and metabolism of Arabidopsis plants associated with high concentration of carbon dioxide. Plant Physiol. 160:1781-1794.

Rogers, A., B.U. Fischer, J. Bryant, M. Frehner, H. Blum, C.A. Raines, and S.P. Long. 1998. Acclimation of photosynthesis to elevated $\mathrm{CO}_{2}$ under low-nitrogen nutrition is affected by the capacity for assimilate utilization: Perennial ryegrass under free-air $\mathrm{CO}_{2}$ enrichment. Plant Physiol. 118:683-689.
Rosenthal, D.M., A.M. Locke, M. Khozaei, C.A. Raines, S.P. Long, and D.R. Ort. 2011. Over-expressing the $C_{3}$ photosynthesis cycle enzyme sedoheptulose-1,7-bisphosphatase improves photosynthetic carbon gain and yield under fully open air $\mathrm{CO}_{2}$ fumigation (FACE). BioMed Central Plant Biol. 11:123-135.

Shi, H., T. Ye, and Z. Chan. 2013. Comparative proteomic and physiological analyses reveal the protective effect of exogenous polyamines in the bermudagrass (Cynodon dactylon) response to salt and drought stresses. J. Proteomic Res. 12:4951-4964.

Solomon, S., D. Qin, M. Manning, M. Marquis, K. Averyt, and M. Tignor. 2007. IPCC Climate change 2007: The physical science basis. In: H.L. Miller and Z. Chen (eds.). Contribution of working groups I, II, and III to the fourth assessment report of the intergovernmental panel on climate change. Cambridge Univ. Press, Cambridge, UK.

Song, Y., J. Yu, and B. Huang. 2014. Elevated $\mathrm{CO}_{2}$-mitigation of high temperature stress associated with maintenance of positive carbon balance and carbohydrate accumulation in kentucky bluegrass. PLoS One 9:e89725.

Sparla, F., M. Zaffagnini, N. Wedel, R. Scheibe, P. Pupillo, and P. Trost. 2005. Regulation of photosynthetic GAPDH dissected by mutants. Plant Physiol. 138:2210-2219.

Sun, J., H. Luo, J. Fu, and B. Huang. 2013. Classification of genetic variation for drought tolerance in tall fescue using physiological traits and molecular markers. Crop Sci. 53:647-654.

Taiz, L. and E. Zeiger. 2010. Plant physiology. 5th ed. Sinauer Assoc., Sunderland, MA.

Topp, G.C., J.L. Davis, and A.P. Annan. 1980. Electromagnetic determination of soil water content: Measurements in coaxial transmission lines. Water Resources Res. 16:574-582.

$\mathrm{Vu}$, J.C.V. and L.H. Allen, Jr. 2009. Growth at elevated $\mathrm{CO}_{2}$ delays the adverse effects of drought stress on leaf photosynthesis of the $\mathrm{C}_{4}$ sugarcane. J. Plant Physiol. 166:107-116.

Vu, J.C.V., J.T. Baker, A.H. Pennanen, L.H. Allen, Jr., G. Bowes, and K.J. Boote. 1998. Elevated $\mathrm{CO}_{2}$ and water deficit effects on photosynthesis, ribulose bisphosphate carboxylase-oxygenase, and carbohydrate metabolism in rice. Physiol. Plant. 103:327339.

Wall, G.W., T.J. Brooks, N.R. Adam, A.B. Cousins, B.A. Kimball, P.J. Pinter, Jr., R.L. LaMorte, J. Triggs, M.J. Ottman, S.W. Leavitt, A.D. Matthias, D.G. Williams, and A.N. Webber. 2001. Elevated atmospheric $\mathrm{CO}_{2}$ improved sorghum plant water status by ameliorating the adverse effects of drought. New Phytol. 152:231-248.

$\mathrm{Xu}, \mathrm{C}$., Y. Xu, and B. Huang. 2008. Protein extraction for twodimensional gel electrophoresis of proteomic profiling in turfgrass. Crop Sci. 48:1608-1614.

$\mathrm{Xu}, \mathrm{C}$. and B. Huang. 2010a. Differential proteomic responses to water stress induced by PEG in two creeping bentgrass cultivars differing in stress tolerance. J. Plant Physiol. 167:1477-1485.

$\mathrm{Xu}, \mathrm{C}$. and B. Huang. 2010b. Differential proteomic response to heat stress in thermal Agrostis scabra and heat-sensitive Agrostis stolonifera. Physiol. Plant. 139:192-204.

$\mathrm{Xu}, \mathrm{C}$. and B. Huang. 2010c. Comparative analysis of drought responsive proteins in kentucky bluegrass cultivars contrasting in drought tolerance. Crop Sci. 50:2543-2552.

$\mathrm{Xu}, \mathrm{C}$. and B. Huang. 2012a. Comparative analysis of proteomic responses to single and simultaneous drought and heat stress for two kentucky bluegrass cultivars. Crop Sci. 52:1246-1260.

$\mathrm{Xu}, \mathrm{C}$. and B. Huang. 2012b. Proteins and metabolites regulated by trinexapac-ethyl in relation to drought tolerance in kentucky bluegrass. J. Plant Growth Regul. 31:25-37.

Yang, Y., H.-B. Kwon, H.-P. Peng, and M.-C. Shih. 1993. Stress responses and metabolic regulation of glyceraldehyde-3-phosphate dehydrogenase genes in Arabidopsis. Plant Physiol. 101:209-216.

$\mathrm{Yu}$, J., L. Chen, M. Xu, and B. Huang. 2012. Effects of elevated $\mathrm{CO}_{2}$ on physiological responses of tall fescue to elevated temperature, drought stress, and the combined stresses. Crop Sci. 52:18481858 . 
Yu, J., Z. Yang, D. Jespersen, and B. Huang. 2014. Photosynthesis and protein metabolism associated with elevated $\mathrm{CO}_{2}$-mitigation of heat stress damages in tall fescue. Environ. Expt. Bot. 99:75-85.

Yu, J., L. Sun, N. Fan, Z. Yang, and B. Huang. 2015. Physiological factors involved in positive effects of elevated carbon dioxide concentration on bermudagrass tolerance to salinity stress. Environ. Expt. Bot. 115:20-27.

Zhang, D.-Y., G.-Y. Chen, Z.-Y. Gong, J. Chen, Z.-Y. Yong, J.-G. Zhu, and D.-Q. Xu. 2005. Ribulose-1,5-bisphosphate regeneration limitation in rice leaf photosynthetic acclimation to elevated $\mathrm{CO}_{2}$. Plant Sci. 175:348-355.

Zhao, Y., H. Du, Z. Wang, and B. Huang. 2011. Identification of proteins associated with water-deficit tolerance in $\mathrm{C}_{4}$ perennial grass species, Cynodon dactylon $\times$ Cynodon transvaalensis and Cynodon dactylon. Physiol. Plant. 141:40-55.

Ziska, L.H. and A.H. Teramura. 1992. $\mathrm{CO}_{2}$ enhancement of growth and photosynthesis in rice (Oryza sativa) modification by increased ultraviolet-B radiation. Plant Physiol. 99:473-481. 